\title{
Risk assessment and management frameworks for carbon capture and geological storage: a global perspective
}

\section{Patricia Larkin*, William Leiss and Daniel Krewski}

\author{
McLaughlin Centre for Population Health Risk Assessment, \\ University of Ottawa, Room 216A, \\ 600 Peter Morand Crescent, K1G 5Z3, Ottawa, Ontario, Canada \\ Email: plarkin@xplornet.com \\ Email: leissw@queensu.ca \\ Email: dkrewski@uottawa.ca \\ *Corresponding author
}

\begin{abstract}
Carbon capture and storage (CCS) is included in the list of technological processes that could reduce point source carbon dioxide emissions that contribute to climate change. For geological storage projects, global frameworks for environmental and human health risk assessment (RA) and risk management (RM) have been developed within various regional and national jurisdictions as well as by non-government organisations since the 2005 Intergovernmental Panel on Climate Change Special Report on CCS. This article provides an updated compendium of elaborated RA/RM frameworks in leading jurisdictions for CCS in the regulatory and non-regulatory contexts including online resources. Using a 3- or 4-step RA, there is an emphasis on storage site selection and characterisation; an iterative approach is recommended for RM emphasising monitoring and re-assessment; and other risk-based considerations such as communications and transparency are discussed more frequently in non-government guidance. Comprehensive risk estimation is not yet promoted.
\end{abstract}

Keywords: carbon capture; regulatory framework; risk assessment; risk management; international.

Reference to this paper should be made as follows: Larkin, P., Leiss, W. and Krewski, D. (2019) 'Risk assessment and management frameworks for carbon capture and geological storage: a global perspective', Int. J. Risk Assessment and Management, Vol. 22, Nos. 3/4, pp.254-285.

Biographical notes: Patricia Larkin is a Post-Doctoral Fellow at the University of Ottawa. Her field of research, population health, considers structural and intermediary determinants of health and their interactions, with a goal to protect or improve human health. With a focus on applied risk management, she is undertaking research, writing and project management at the McLaughlin Centre for Population Health Risk Assessment and the Institute for Science Society and Policy. She is an active member of the Society for Risk Analysis. She holds her Master's in Geography and Graduate Diploma in Population Health Risk Assessment and Management. 
William Leiss is a Fellow and Past-President (1999-2001) of the Royal Society of Canada and an Officer in the Order of Canada. He is currently a scientist at the McLaughlin Centre for Population Health Risk Assessment, University of Ottawa. From 1999 to 2004, he held the NSERC/SSHRC/Industry Research Chair in the Risk Communication and Public Policy at the Haskayne School of Business, University of Calgary. From 1994 to 1999, he held the Eco-Research Chair in Environmental Policy at the Queen's University (Ontario). He is the author of Risk and Responsibility (1994), Mad Cows and Mother's Milk: The Perils of Poor Risk Communication (1997, 2004); in the Chamber of Risks: Understanding Risk Controversies (2001), all from McGill-Queen's University Press.

Daniel Krewski is a Professor of Epidemiology and Community Medicine at the University of Ottawa, where he also serves as Scientific Director of the McLaughlin Centre for Population Health Risk Assessment. His research interests include epidemiology, biostatistics, health risk assessment and risk management. He is a Fellow of the Society for Risk Analysis, the American Statistical Association and a national affiliate of the US National Academy of Sciences. He holds the Natural Sciences and Engineering Research Council of Canada Chair in Risk Science at the University of Ottawa.

\section{Introduction}

Carbon capture and storage (CCS) is a technological process that could reduce industrial point source greenhouse gas emissions that contribute to climate change (IEA, 2009, 2013, 2016; IPCC, 2005, 2014). In order to promote its uptake worldwide, stakeholders have repeatedly identified the need for a legal and regulatory framework within international, regional, national and sub-national jurisdictions (Baker and McKenzie, 2011; Carbon Sequestration Leadership Forum, 2013; $\mathrm{CO}_{2}$ Capture Project, 2010, 2012; Condor et al., 2011a; GCCSI, 2010, 2013, 2014; IEA, 2009, 2010a, 2010b, 2011, 2013, 2018; Keith et al., 2005; Klass and Wilson, 2008; Leiss and Krewski, 2019; Pollak and Wilson, 2009; US Environmental Protection Agency, 2010; Wilson et al., 2003). Issues include carbon dioxide $\left(\mathrm{CO}_{2}\right)$ ownership, liability, emission credits and project funding; health and environmental protection; public engagement; monitoring; and provisions specific to cross-border contexts. The IEA (2010a) (Table 1) suggested these will be addressed through existing laws and regulations, as they stand and with amendment and through new regulations aimed at specific components of the CCS value chain.

International regulatory developments are continually updated. Foremost among these efforts are the International Energy Agency (IEA), IEA Greenhouse Gas R\&D Programme (IEAGHG), Global Carbon Capture Storage Institute (GCCSI) and work by University College London - Carbon Capture Legal Programme, now housed by GCCSI. For instance, the IEA established an annual legal and regulatory review in support of CCS projects (IEA, 2010b, 2011, 2014) and the GCCSI published a legal and regulatory indicator assessment (GCCSI, 2015, 2017). Rather than being limited to report-based annual updates, the regulatory context for CCS in active jurisdictions is also available online through the CCS Law and Regulations Database (IEA, 2018). A user may search by jurisdiction or by issue; for example, CCS legislation is cross-listed with provisions regarding regulatory scope and definitions, land rights, exploration and injection 
permitting (including provision for environmental protection and impact assessment), operations and closing and management of long-term responsibilities and liabilities.

Table 1 IEA key regulatory issues

\begin{tabular}{|c|c|c|c|c|}
\hline Regulatory issue & $\begin{array}{l}\text { Broad } \\
\text { regulations }\end{array}$ & $\begin{array}{c}\text { Existing } \\
\text { regulations } \\
\text { applied to } \\
\text { CCS }\end{array}$ & $\begin{array}{l}C C S \text { specific } \\
\text { regulations }\end{array}$ & $\begin{array}{l}\text { Emerging } \\
\quad C C S \\
\text { regulations }\end{array}$ \\
\hline \multicolumn{5}{|l|}{ Full CCS chain } \\
\hline Protecting human health & & $\mathrm{X}$ & & \\
\hline $\begin{array}{l}\text { The role of environmental } \\
\text { impact assessment }\end{array}$ & & $\mathrm{X}$ & & \\
\hline $\begin{array}{l}\text { Composition of the } \mathrm{CO}_{2} \\
\text { stream }\end{array}$ & & $\mathrm{X}$ & & \\
\hline $\begin{array}{l}\text { Corrective measures and } \\
\text { remediation measures }\end{array}$ & & & $\mathrm{X}$ & \\
\hline \multicolumn{5}{|l|}{ Capture } \\
\hline $\mathrm{CO}_{2}$ capture & & & $\mathrm{X}$ & \\
\hline \multicolumn{5}{|l|}{ Transportation } \\
\hline $\mathrm{CO}_{2}$ transportation & & & $\mathrm{X}$ & \\
\hline \multicolumn{5}{|l|}{ Storage - Science } \\
\hline $\begin{array}{l}\text { Regulating site selection } \\
\text { and characterisation } \\
\text { activities }\end{array}$ & & & $\mathrm{X}$ & \\
\hline $\begin{array}{l}\text { Definitions and } \\
\text { terminology applicable to } \\
\mathrm{CO}_{2} \text { storage regulations }\end{array}$ & & & $\mathrm{X}$ & \\
\hline $\begin{array}{l}\text { Authorisation of storage } \\
\text { site exploration activities } \\
\text { (permitting) }\end{array}$ & & & $\mathrm{X}$ & \\
\hline $\begin{array}{l}\text { Authorisation of storage } \\
\text { activities (permitting) }\end{array}$ & & & $\mathrm{X}$ & \\
\hline $\begin{array}{l}\text { Authorisation for storage } \\
\text { site closure (permitting) }\end{array}$ & & & $\mathrm{X}$ & \\
\hline \multicolumn{5}{|l|}{ Storage and monitoring } \\
\hline $\begin{array}{l}\text { Third-party access to } \\
\text { storage site and } \\
\text { infrastructure }\end{array}$ & & $\mathrm{X}$ & & \\
\hline Project inspections & & & $\mathrm{X}$ & \\
\hline $\begin{array}{l}\text { Monitoring, reporting and } \\
\text { verification requirements }\end{array}$ & & & $\mathrm{X}$ & \\
\hline \multicolumn{5}{|l|}{ Public Engagement } \\
\hline $\begin{array}{l}\text { Engaging the public in } \\
\text { decision making }\end{array}$ & & $\mathrm{X}$ & & \\
\hline
\end{tabular}

Source: Modified from IEA (2010a, p.17) 
Table 1 IEA key regulatory issues (continued)

\begin{tabular}{|c|c|c|c|c|}
\hline Regulatory issue & $\begin{array}{l}\text { Broad } \\
\text { regulations }\end{array}$ & $\begin{array}{l}\text { Existing } \\
\text { regulations } \\
\text { applied to } \\
\text { CCS }\end{array}$ & $\begin{array}{l}C C S \text { specific } \\
\text { regulations }\end{array}$ & $\begin{array}{l}\text { Emerging } \\
\quad C C S \\
\text { regulations }\end{array}$ \\
\hline \multicolumn{5}{|l|}{ International } \\
\hline $\begin{array}{l}\text { Transboundary } \\
\text { movement of } \mathrm{CO}_{2}\end{array}$ & $\mathrm{X}$ & & & \\
\hline $\begin{array}{l}\text { International laws re } \\
\text { marine environment }\end{array}$ & $\mathrm{X}$ & & & \\
\hline \multicolumn{5}{|l|}{ Emerging } \\
\hline CCS ready & & & & $\mathrm{X}$ \\
\hline $\begin{array}{l}\text { Using CCS for } \\
\text { biomass-based sources }\end{array}$ & & & & $\mathrm{X}$ \\
\hline $\begin{array}{l}\text { Understanding enhanced } \\
\text { hydrocarbon recovery } \\
\text { with CCS }\end{array}$ & & & & $\mathrm{X}$ \\
\hline $\begin{array}{l}\text { Sharing knowledge and } \\
\text { experience }\end{array}$ & & & & $\mathrm{X}$ \\
\hline \multicolumn{5}{|c|}{ Definition, rights, liability, financial } \\
\hline Classifying $\mathrm{CO}_{2}$ & $\mathrm{X}$ & & & \\
\hline Property rights & $\mathrm{X}$ & & & \\
\hline $\begin{array}{l}\text { Competition with other } \\
\text { users and preferential } \\
\text { rights issue }\end{array}$ & $\mathrm{X}$ & & & \\
\hline $\begin{array}{l}\text { Providing incentives for } \\
\text { CCS }\end{array}$ & $\mathrm{X}$ & & & \\
\hline $\begin{array}{l}\text { Liability during the } \\
\text { project period }\end{array}$ & & & $\mathrm{X}$ & \\
\hline $\begin{array}{l}\text { Liability during the } \\
\text { postclosure period }\end{array}$ & & & $\mathrm{X}$ & \\
\hline $\begin{array}{l}\text { Financial contributions } \\
\text { to post-closure }\end{array}$ & & & $\mathrm{X}$ & \\
\hline $\begin{array}{l}\text { Scope of framework and } \\
\text { prohibitions }\end{array}$ & & & $\mathrm{X}$ & \\
\hline
\end{tabular}

Source: Modified from IEA (2010a, p.17)

With a focus on environmental and human health risk assessment and risk management (RA/RM), both regulators and non-government organisations have published elaborated frameworks and guidance documents aimed at ensuring safe and effective project development and operations. Previous analysis of RA/RM provisions was completed for the London and OSPAR Conventions, the then-draft European Union CCS Directive, then-draft USEPA Underground Injection Control Program rule and national and sub-national provisions in Canada and Australia (Condor et al., 2011a, 2011b; Forbes et al., 2009; Stenhouse et al., 2009). Pollak and Wilson (2009) compared three regulatory approaches, including provisions for performance objectives and RA then being developed for the EPA and two states. Dixon et al. (2015) provided a detailed review of legal and regulatory developments since IPCC (2005), including RA/RM, with a focus on 
the treatment of geological storage in international jurisdictions including the London Convention, OSPAR treaties, European Union CCS Directive and United Nations Framework Convention on Climate Change (UNFCCC) modalities and procedures for carbon dioxide capture and storage in geological formations as clean development mechanism (CDM) project activities.

With the potential for thousands of CCS geological storage projects at industrial sites worldwide, contributing an estimated $12 \% \mathrm{CO}_{2}$ emissions reductions through 2050 (IEA, 2016), this paper extends previous work by providing an updated compendium of elaborated RA/RM frameworks for CCS in the regulatory and non-regulatory contexts. Section 2 includes international regulatory-based frameworks approved in Europe-based cross-national jurisdictions, Australia and the USA. Canadian guidance is described in detail by Larkin et al. (2019). Section 3 is focused on non-regulatory frameworks developed by the World Resources Institute, US National Energy Technology Laboratory (NETL), DNV GL (formerly Det Norske Veritas), CSA Group and several resources published online. Analysis in Section 4 describes commonalities and differences in mandatory requirements and voluntary considerations for RA, RM and other risk-based issues, also identifying issue areas stakeholders may be concerned about if and when the number of potential CCS projects increases in the coming years.

\section{International regulatory-based frameworks}

\subsection{Cross-national jurisdictions}

The contracting parties to the International Maritime Organization's (IMO) London Convention adopted the Risk Assessment and Management Framework for $\mathrm{CO}_{2}$ Sequestration in Sub-Seabed Geological Structures (RAMF) (IMO, 2006) in association with Annex 1 amendment of the London Protocol to include $\mathrm{CO}_{2}$ sequestration in sub-seabed geological formations. The framework allows characterisation of the potential risks posed by $\mathrm{CO}_{2}$ sequestration on a site-specific basis and the collection of all necessary information for developing a management strategy to address uncertainties and residual risks. The RA/RM guidance suggests six steps: problem formulation; site selection and characterisation; exposure assessment; effects assessment; risk characterisation; and risk management. The specific guidelines on assessment of $\mathrm{CO}_{2}$ streams for disposal into sub-seabed geological formations under the protocol (IMO, 2012) provides advice on how to capture and sequester $\mathrm{CO}_{2}$ in a manner that meets all the requirements of the London Convention and is safe for the marine and atmospheric environments over the short- and long-term.

In 2007, amendments by the contracting parties to the OSPAR convention for the Protection of the Marine Environment of the North-East Atlantic permitted $\mathrm{CO}_{2}$ storage in accordance with Annex 1, 'Prevention and elimination of pollution from land-based sources'. The OSPAR guidelines for risk assessment and management of storage of $\mathrm{CO}_{2}$ streams in geological formations (FRAM) (OSPAR Commission, 2007) were also approved, based in part on the RAMF. The guidelines identify the elements of a RA framework to be applied to both onshore and other geological $\mathrm{CO}_{2}$ storage projects (Stenhouse et al., 2009): problem formulation; site selection and characterisation; exposure assessment; effects assessment; risk characterisation; and risk management. A full RA/RM process must be completed to the satisfaction of the competent authority 
such that "the storage will not lead to significant adverse consequences for the marine environment, human health and other legitimate uses of the maritime area" (OSPAR Commission, 2007). Permitting requires a RM Plan. These guidelines are mandatory and are in force, although their application includes some flexibility (Dixon et al., 2015).

The European Union (EU) CCS Directive entered into force in 2011. The Directive established a legal framework for the environmentally safe geological storage of carbon dioxide to contribute to mitigating climate change (European Union, 2009). The goal is permanent containment, with no significant risk of leakage or harm, in order to prevent or eliminate as far as possible negative effects and risk to the environment and human health and to prevent adverse effects on the security of the transport network or storage sites (European Union, 2009). Seven other pieces of EU environmental legislation were amended to remove legal barriers to geological storage of $\mathrm{CO}_{2}$, including the Strategic Environmental Assessment (SEA) Directive (European Union, 1985), the Environmental Impact Assessment Directive (European Union, 2014) and the Directive on Integrated Pollution Prevention and Control (European Union, 2008). RA is mandatory and framed in a similar way to the RAMF and the FRAM. The assessment requires: hazard characterisation; exposure assessment; effects assessment; risk characterisation, including geological characteristics and use of computerised storage simulations; sources of uncertainty and evaluation of ways to reduce uncertainty. Several non-binding detailed guidance documents were published (European Commission, 2011a, 2011b, 2011c). Moreover, guidelines for site monitoring are contained in Annex II, including provisions for a monitoring plan, corrective measures plan, update to the monitoring plan and postclosure plan. With respect to potential leakage, these guidelines are implemented in relation to the monitoring and reporting of greenhouse gas emissions pursuant to the EU emissions trading scheme (European Commission, 2012b). The EC completed one opinion on adherence to the CCS Directive (European Commission, 2012a) and two implementation reports (European Commission, 2018). Furthermore, an evaluation of the Directive considered its effectiveness, efficiency, coherence, relevance and EU added value (Triple et al., 2015). With limited advancement of CCS projects since the Directive came into force, the results of the review did not lead to detailed comments on its effectiveness in ensuring installations are safe for the environment and human health.

The UNFCCC (2011) modalities and procedures for carbon dioxide capture and storage in geological formations as a CDM enables industrialised countries to earn certified emission reduction credits applied to targets under the Paris Agreement (and previously the Kyoto Protocol) for CCS projects undertaken in developing countries. There are mandatory requirements for the selection and characterisation of the geological storage site; risk and safety assessment for human health and ecosystems; and monitoring. Site characterisation shall consider dynamic behaviour, sensitivity characterisation and RA using dynamic modelling. The risk and safety assessment must include hazard identification, exposure assessment, effects assessment, risk characterisation and contingency planning for large incidents, for the full chain of $\mathrm{CO}_{2}$ capture, transport and storage, including surrounding environments. RA shall also inform the site development and management plan, approaches for enhanced monitoring activities and the basis for remedial measures and response plans. RA shall include a communication plan and shall be used to inform environmental and socio-economic impact assessments. No projects are listed on the UNFCCC CDM search portal https://cdm.unfccc.int/Projects/projsearch.html. 


\subsection{Australia}

At the national and sub-national levels, Australia Commonwealth and State CCS legislation and regulations apply to any greenhouse gas substance, therefore not limited to $\mathrm{CO}_{2}$. The Commonwealth government is responsible for offshore operations greater than 3 nautical miles from land. Transport is normally regulated through the Australian Pipeline standard, as required by the Petroleum and Geothermal Energy Act.

The storage regulatory framework is underpinned by the Offshore Petroleum and Greenhouse Gas Storage Act (OPGGS Act) 2006 (Australian Government, 2011c) and regulations. The Department of Industry administers the Greenhouse Gas Injection and Storage Regulations (Australian Government, 2011a), where risk focuses on seepage and migration that could affect other petroleum resources. A proposed site plan must include the spatial extent and predictions of the behaviour of the greenhouse gas (GHG) substance to be stored; RA for plume migration, including engineering enhancements; and RA/RM containment control and remediation strategies. Monitoring must satisfy that any significant events, as well as variations from predicted behaviour, will be detected in a timely fashion. Required site plans, storage and monitoring plans could therefore also be of benefit to human and environmental RA/RM. The regulation also outlines requirements for determining 'significant risks of a significant adverse impact' (with respect to costs of event); incident reporting for any variations from the behaviour predicted and any leakage from wells; a decommissioning plan and site closure certificates; and requirements to report on consultations with stakeholders such as other users of the sea.

The National Offshore Petroleum Safety and Environmental Management Authority (NOPSEMA) was established in 2012 and is responsible for regulating the health and safety, well integrity and environmental management of all offshore petroleum facilities in Commonwealth waters, as well as in coastal waters where State powers have been conferred. Following the Montara Well Blowout incident in 2009 and subsequent inquiry (Barrett, 2015), the objectives of the OPGGS were extended from economic optimisation of field operations for petroleum recovery to a greater emphasis on safety. Broad powers include dealing with serious situations and contingencies, including cessation of operations.

With respect to health and safety, the OPGGS (Safety) Regulations (Australian Government, 2009) outline requirements for operators to submit a Safety Case that describes hazards with a potential to cause a major accident event; provides a detailed and systematic assessment of associated risk, including likelihood and consequence; and identifies technical and other control measures that are necessary to reduce risk to a level that is as low as reasonably practicable (ALARP), further explained in NOPSEMA (2015).

The OPGGS (Environment) Regulation (Australian Government, 2014) sets out the content and criteria for acceptance of the Environment Plan. This provides an evaluation of impacts and risks; an implementation strategy that ensures that any impacts are ALARP; and, a report on consultations. In addition to these mandatory regulatory provisions, several guidance documents for the preparation of submissions and consultation requirements have also been produced (NOPSEMA, 2015, 2018a, 2018b).

The Resource Management and Administration (OPGGS) Regulation (Australian Government, 2011b) requires a well operations management plan (WOMP) to include, among other provisions, a description of: 
- the risk management process used to identify and assess risks to the integrity of the well

- lifecycle risk reduction and risk control measures, including performance standards and measurement, for the integrity of the well to as low as reasonably practicable

- the monitoring, audit and well integrity assurance processes.

The WOMP is the 'sole permissioning' provision (Barrett, 2015), with guidance for a complete submission under the regulation (NOPSEMA, 2016).

State governments are responsible for both onshore sites and sites falling within a 3 nautical mile offshore limit. Near shore legislation typically mirrors that of the Commonwealth. Victoria was the first to enact both an onshore and offshore regulatory framework. Here, the Greenhouse Gas Geological Sequestration Act and regulations (State of Victoria, 2008, 2009) address large-scale commercial and sustainable injection and permanent storage of GHG substances in the onshore. An injection testing plan must detail how risks to public health or the environment will be prevented and an environmental management plan, including environmental RA, must be prepared. Victoria will not accept liability after site closure.

Similarly, Queensland enacted the Greenhouse Gas Storage Act and Regulations (Queensland Government, 2009, 2010), including requirements, without elaboration, for injection test plans to assess whether there is any risk to public health or the environment and risk mitigation.

South Australia amended the Petroleum and Geothermal Energy Act and Regulations (Government of South Australia, 2018) in order to specify the Environment Protection Authority and Safe Work South Australia as agencies that must be consulted in project approval. All regulated activities must be undertaken in accordance with a Statement of Environmental Objectives, developed on the basis of an Environmental Impact Report. The State also requires submission of fitness-for-purpose (FFP) RA of facilities once every five years, with respect to public health and safety, the environment and, where applicable, the security of the natural gas supplies (Government of South Australia, 2012).

In Western Australia, the injection and permanent storage of GHGs in underground geological formations is currently not regulated, with the exception of the Gorgon Gas Project via the Barrow Island Act 2003 (Western Australia, 2003). Onshore transport and storage of GHGs could be permitted through the Petroleum and Geothermal Energy Legislation Amendment Bill 2013 if this receives Royal Assent (IEA, 2014; Western Australia, 2013).

\section{$2.3 U S A$}

The US Environmental Protection Agency's (EPA) Underground Injection Control (UIC) Class VI Program for Carbon Dioxide Geologic Sequestration Wells was approved in 2010 (US Environmental Protection Agency, 2011). The overall purpose of the UIC is to protect underground sources of drinking water and the addition of the Class VI Program was deemed necessary in order to address the relative buoyancy of $\mathrm{CO}_{2}$, its mobility in the subsurface, its corrosivity in the presence of water and the large injection volumes anticipated at CCS sequestration projects. The Class VI Program has more comprehensive operating requirements, mechanical integrity testing and monitoring, 
emergency and remedial response criteria than applied to Class II wells which permit $\mathrm{CO}_{2}$ injection for enhanced oil or gas recovery (US Environmental Protection Agency, 2011). The Class VI rule does not include a mandatory requirement for RA/RM.

As part of permitting, an operator may be required to submit site-specific RM plans to address produced water use and disposal, closure, post-injection monitoring, mitigation and remediation. States may apply for primacy enforcement responsibility. In addition to administrative details, voluntary guidance describes the recommended approach to meet regulatory requirements in the following areas:

- Project Plan Development (US Environmental Protection Agency, 2012b).

- Well Site Characterisation (US Environmental Protection Agency, 2013c).

- Well Construction (US Environmental Protection Agency, 2012a).

- Well Testing and Monitoring (US Environmental Protection Agency, 2013d).

- Area of Review (AoR) Evaluation and Corrective Action (US Environmental Protection Agency, 2013a).

- Draft Guidance on Transitioning Class II Wells to Class VI Wells (US

Environmental Protection Agency, 2013b), addressing the EPA's concern for increased risk to USDWs where a well or group of wells is first used for $\mathrm{CO}_{2}$ injection for enhanced oil recovery and then converted to maximise $\mathrm{CO}_{2}$ volumes for permanent storage.

A complementary linkage exists between the UIC Class VI Program and Greenhouse Gas Reporting Program, Subpart RR, Geologic Sequestration of Carbon Dioxide (US Environmental Protection Agency, 2018b). The latter requires storage site owners or operators of facilities that inject $\mathrm{CO}_{2}$ underground for sequestration to submit a monitoring, reporting and verification plan to the EPA for review and approval (Dixon et al., 2015). Details must include a delineation of the maximum monitoring area and "identification and evaluation of potential surface leakage pathways in the maximum monitoring area and the likelihood, magnitude and timing, of surface leakage of $\mathrm{CO}_{2}$ through these pathways" [US Environmental Protection Agency, (2017), p.Subpart RR]. This may be considered, in effect, a required assessment of the risk of leakage.

Three examples of CCS regulatory frameworks in US States, with particular focus on risk, are included here. Under the Kansas Carbon Dioxide Reduction Act, the State Corporation Commission adopted rules and regulations establishing requirements, procedures and standards for the safe and secure injection of $\mathrm{CO}_{2}$ and maintenance of underground storage of $\mathrm{CO}_{2}$ in terms of both public health and safety or usable water (Kansas State Corporation Commission, 2010). The Mississippi Geologic Sequestration of Carbon Dioxide Act (State of Mississippi, 2013) established a regulatory framework that gives the Department of Environmental Quality and the State Oil and Gas Board the authority to regulate the storage of $\mathrm{CO}_{2}$. In part, approval of a storage reservoir requires both assurance of no reasonable risk to other formations (such as fresh water, oil, gas or other commercial mineral deposits) and endangerment to human life or hazardous conditions to property. The legislation points to the USEPA Class VI Program regarding wells, although there is no RA/RM elaboration. Thirdly, in North Dakota (State of North Dakota, 2009), legislation covers the geologic storage of $\mathrm{CO}_{2}$; gives authority to the North Dakota Industrial Commission for the construction, operation and closure of $\mathrm{a}_{2}$ 
storage facility; and provides a general framework for long-term liability. The law sets out the permitting requirements, criteria, fees and process, as well as penalties for non-compliance. There is no RA/RM elaboration, except for required monitoring. No guidance or regulations appear to have been developed. North Dakota was the first State to receive primacy enforcement for carbon sequestration wells (US Environmental Protection Agency, 2018a).

\section{Non-regulatory elaborated frameworks}

\subsection{World Resources Institute}

WRI attempts to publish "timely, scholarly treatment of a subject of public concern" [World Resources Institute, (2008), p.2]. Guidelines for Carbon Dioxide Capture Transport and Storage were developed through a diverse multi-stakeholder consultative process involving business, non-governmental organisations, academia and others. The guidelines suggest a comprehensive RA for the capture chain would consider materials, procedures and processes that are fit-for-purpose, including assessment of environmental impacts of any co-constituents and the benefits of $\mathrm{CO}_{2}$ emissions reductions. Non- $\mathrm{CO}_{2}$ environmental impacts on air, water and solid waste, would also be included. In transport, RA would address pipeline design and operations, safety and integrity, siting and access and tariff regulation. Meeting higher than regulated safety standards is suggested as a minimum best practice, along with options for increasing due diligence on placement, controls and monitoring.

Storage is discussed in greater detail. The primary risk is identified as the potential adverse impacts of potential $\mathrm{CO}_{2}$ leakage on human health and the environment. RA and measurement, monitoring and verification (MMV) are discussed as cross-cutting issues, including an iterative and integrated RA/MMV program. The recommended stages of RA include hazard identification (confining zone or caprock failure, wells, faults and fractures, seismic events) and the evaluation of receptor impacts (effects assessment on humans and ecosystems, groundwater and atmospheric release). The guidelines include a conceptual approach to selecting MMV tools, based on benefits and costs. Mitigation or remediation planning is also discussed.

\subsection{US Department of Energy, NETL}

The NETL has published several elaborated frameworks in the form of best management practices (BMP), some of which are now the third edition. The manuals share experiences and lessons drawn from the risk analysis and numerical simulation activities of the Regional Carbon Sequestration Partnership (RCSP) field and large-scale development phase projects. The BMPs are "intended to provide a holistic approach to carrying out a geologic storage project, from inception to completion" [NETL, (2017d), p. 13]

In Risk Management and Simulation for Geologic Storage Projects (NETL, 2017c) risk characterisation is sub-divided into exposure and effects assessment, determination of risk probabilities and impacts. RA methods and tools published by a range of organisations and institutions are listed. The manual suggests that RA provide the basis for the RM program and that mitigation and control plans rely on monitoring data. 
Best practices for carbon storage systems and well management activities (NETL, 2013) shares lessons learned regarding site-specific management for CCS well systems (primarily with regard to the EPA UIC Class VI Well program), with a focus on planning, permitting, design, drilling, implementation and decommissioning of wells for geologic storage projects RA (risk analysis, in their terminology) is mentioned with regard to gauging the importance of data gaps; RA is positioned as an iterative process to characterise the site and project and determine impacts on project budget. RM is directly linked to RA, where post-injection operations anomalies observed through monitoring may need to be re-evaluated and corrective measures (mitigation plans) implemented, although potential remedial work and safety plans are not elaborated.

Monitoring, verification and accounting (MVA) for Geologic Storage Projects (NETL, 2017a) suggests that site characterisation and associated RA focus on identifying and quantifying potential risks to humans and the environment prior to operations and that these risks play a significant role in determining an appropriate CCS monitoring program. MVA in turn supports an interactive RA process. An earlier version included the stated goal that monitoring demonstrates that " $99 \%$ of injected carbon dioxide $\left(\mathrm{CO}_{2}\right)$ remains in the injection zones" (up from $95 \%$ in the 2009 edition), retention figures that are based on the ability to detect $5 \%$ and $1 \%$ leakage rates.

In Public Outreach and Education for Carbon Storage Projects (NETL, 2017b), the guidance notes that "any concerns that have been identified, including perceived risks, should be addressed in language and formats suited to the intended audiences" [NETL, (2017b), p.32]. However, it also notes that "public outreach, even when done well, does not guarantee public acceptance of a given $\mathrm{CO}_{2}$ storage project" (2017b, p.15). Eleven best practices for designing an outreach program are described.

Other NETL publications include site screening, site selection and site characterisation for Geologic Storage Projects (NETL, 2017d), with a focus on factors that would support a go/no go project decision. Project risks include financial, public acceptance, political, liability and uncertainty issues. Key technical risks include faults and fractures, fate of $\mathrm{CO}_{2}$ and issues with geomechanical $/ \mathrm{mechanical} /$ flow models. Social context analysis is suggested as a way for project developers to understand potential perceived benefits and risks of the project for the community.

\subsection{DNV GL (formerly Det Norske Veritas)}

DNV produced numerous elaborated CCS RA/RM guidance documents, with a goal to create consensus among project developers and regulators on proper site selection and management. The company's approval process included feedback from representatives of national regulators, interest organisations, project developers and external stakeholders.

Qualification Procedures for $\mathrm{CO}_{2}$ Capture Technology (Det Norske Veritas, 2010b) covers the three main approaches of pre-combustion, post-combustion and oxy-fuel combustion. A systematic set of activities (technology and threat assessment, development and execution of qualification plan and performance assessment) will play an important role in increasing confidence in new and scaled-up $\mathrm{CO}_{2}$ capture technologies.

Project Specific Guideline for Safe, Reliable and Cost-Effective Transmission of $\mathrm{CO}_{2}$ in Pipelines supplements existing pipeline standards and is applicable to both onshore and offshore installations (Det Norske Veritas, 2010a). The document suggests there is significantly less industry experience for pipelines that carry $\mathrm{CO}_{2}$ and related 
compositions than for hydrocarbons such as natural gas. The RA methodology includes threat identification to an area or to equipment, risk reduction through mitigation and measuring risk reduction results. Human impact is discussed explicitly with regard to $\mathrm{CO}_{2}$ exposure limits for the public and workers. RM includes consideration of pipeline design, safety objectives, population density along the pipeline route, topography, pipeline integrity conditions (monitoring, inspection and reporting), upset conditions and shut-down/re-start operations.

Recommended Practice - Geological Storage of Carbon Dioxide (Det Norske Veritas, 2012) incorporated and combined previous guidance $\mathrm{CO}_{2} \mathrm{QUALSTORE}-$ Selection and Qualification of Sites and Projects for Geological Storage of $\mathrm{CO}_{2}$ and $\mathrm{CO}_{2}$ WELLS Guideline for the risk management of existing wells at $\mathrm{CO}_{2}$ geological storage sites. Based on DNV's seven identified project phases, detailed guidance is provided for site screening and appraisal; inclusions for three permitting stages (exploration, storage, transfer of responsibility); well qualification (appraisal through close phases); and risk management throughout all phases of a CCS project. Transparency and traceability are emphasised. Three risk categories are suggested in evaluation: broadly acceptable or negligible, tolerable or ALARP (similar to Australian regulations), where risk reduction is impracticable or the cost is grossly disproportionate to the improvement gained; and unacceptable, where risks cannot be justified except in extraordinary circumstances.

$\mathrm{CO}_{2}$ RISKMAN Guidance on $\mathrm{CCS} \mathrm{CO}_{2}$ Safety and Environment, Major Accident Hazard Risk Management (Det Norske Veritas, 2013) (with increasing detail in levels $1-4$ ) is focused on management for the $\mathrm{CO}_{2}$ stream that could affect human health or the environment. Integration of RM across the full CCS chain recognises that a number of stakeholders will be involved in a fully integrated project. Hazard identification, RA, risk reduction (including elimination, prevention, control, mitigation and emergency response) and RM measures are described for capture facilities, onshore pipelines, submarine pipelines, wells, offshore injection facilities, intermediate buffer storage and carrier ships. ALARP is also discussed here. The guidance does not consider potential longer term impacts to groundwater quality from $\mathrm{CO}_{2}$ or displacement of other reservoir fluids such as brine.

Risk evaluation is described as the process to compare the level of risk found during the analysis process with risk criteria established when the context was defined. Based on this comparison, the need for risk reduction can be considered. RM includes "suitable and sufficient RA; risk reduction to an acceptable level, including risk treatment hierarchy; optimal capital investment with a view to risk minimisation; a practical strategy to manage each of the primary risk drivers; an effective and reliable combination of measures to implement the strategy; and that project and corporate goals are met for the whole lifetime of the facility" [Det Norske Veritas, (2013), p.4, Level 3].

\subsection{CSA group}

The CSA Standard Z741 - Geological Storage of Carbon Dioxide (CSA Group, 2012) includes, but is not limited to, the safe design, construction, operation, maintenance and closure of facilities (injection wells) and storage sites. The project phases are site screening; site characterisation, assessment and selection; design and development; operational; and post injection and closure. The standard does not apply to the post-closure period. 
RA is to be completed with regard to the natural environment, regional natural resources, infrastructure, human culture, legal and regulatory environment, industry best practices and project management considerations, such that results demonstrate that storage of the $\mathrm{CO}_{2}$ stream at the candidate site(s) does not pose an unacceptable risk to other resources, to the environment and human health, or to project developers, owners and operators. RA includes risk identification, risk analysis and risk evaluation (the likelihood and severity of consequences for each risk scenario), including assessment of uncertainty. Standard Z741 refers to consideration of features, events and processes (FEP), similar to that developed by Quintessa (see on-line resource, below). Risk ranking is discussed with respect to both site selection and injection.

Of note, the Canadian standard was used as the basis for ISO Standard Carbon Dioxide Capture, Transportation and Geological Storage - Geological Storage which contains a clause on Risk Management. The ISO standard is at the approval stage at the time of publication of this compendium and not available publicly. Preparatory work is also underway for ISO Standard Lifecycle risk management for integrated CCS projects (ISO, 2018).

The Global Carbon Capture and Storage Institute (GCCSI) created openCCS in 2011, an online handbook that identifies key processes and steps required in the development and delivery of each component of an integrated CCS project (GCCSI, 2019). Separate webpages consider power capture, transport and storage with a six-step project delivery (Identify, evaluate, define, execute, operate and closure) for each. The most relevant topics for RA/RM include environmental management; health and safety; measuring, monitoring and verification; stakeholder and external relationship management; and exploration RA/RM. The handbook suggests objectives and major deliverables, as well as a list of specific tasks.

\subsection{Online elaborated $R A / R M$ tools and resources}

The WRI created a CCS Regulatory Comparison Matrix 2.0 (World Resources Institute, 2012). Web users can compare 20 identified key issues for CCS regulations, standards and best practice guidelines between four RA/RM frameworks: the WRI CCS Guidelines (Wilson et al., 2008), the IEA Model Regulatory Framework (IEA, 2010a), the US Class VI Well Program (US Environmental Protection Agency, 2011) and the EU CCS Directive (European Union, 2009). Social and environmental criteria are compared between the selected frameworks. The Matrix 2.0 provides transparent, easy-to-access information regarding existing regulations and allows users to assess language and approach. It is also a mechanism for stakeholders to provide input on how CCS regulations could be improved.

While not developed as a RA/RM framework, an extensive on-line resource is Quintessa's $\mathrm{CO}_{2}$ FEP database for $\mathrm{CO}_{2}$ underground storage projects (Quintessa Ltd., 2018). There are eight categories of FEPs: assessment basis; external factors; $\mathrm{CO}_{2}$ storage; $\mathrm{CO}_{2}$ properties, interactions and transport; geosphere; boreholes; near-surface environment; and impacts to humans, flora, fauna or the physical environment. This database can be used as part of systemic assessments of safety and performance.

The GCCSI created openCCS in 2011, an online handbook that identifies key processes and steps required in the development and delivery of each component of an integrated CCS project (GCCSI, 2019). Separate webpages consider power capture, transport and storage with a six-step project delivery (identify, evaluate, define, execute, 
operate and closure) for each. The most relevant topics for RA/RM include environmental management; health and safety; measuring, monitoring and verification; stakeholder and external relationship management; and exploration RA/RM. The handbook suggests objectives and major deliverables, as well as a list of specific tasks.

Last, the $\mathrm{UK} \mathrm{CO}_{2}$ storage evaluation database $\mathrm{CO}_{2}$ stored (The Crown Estate and British Geological Survey, 2016) began as a region-specific subscription-based online resource and is now available free of charge. The database contains derived geological data, storage estimates, risk data and economics for nearly 600 potential $\mathrm{CO}_{2}$ storage units located offshore. Gammer et al. (2011) describe the methodology used to assess the storage potential for both saline aquifers and depleted hydrocarbon fields. Containment risks include seals, faults, lateral migration, wells, formation damage and connectivity. A risk profile (severity and likelihood of impact) is also provided for both costs and capacity of the sites, including descriptions for containment and operational elements of risk. The data include economics analysis based on injection rates per year and undiscounted lifetime costs of chain activities. A Monte Carlo simulation summary is also provided.

\section{Commonalities and differences among RA/RM frameworks worldwide}

With increasingly comprehensive understanding of the many different dimensions of risk associated with CCS, significant contributions to suggested practice in risk assessment and risk management of value chain activities have been published within legislation, regulation, government and non-regulatory guidance documents and online resources. In both the regulatory and non-regulatory contexts, frameworks often refer to and build upon previously existing documentation from within an organisation or as developed by others.

Commonalities and differences are discussed here with respect to RA, RM and other risk-based activities. Tables 2 and 3 detail inclusions in the selected frameworks described here. More CCS RA/RM frameworks address injection and storage phase risks, while fewer provide guidance for capture and transport. Where there is a focus on injection and storage, documents identify four to six project phases from project development through closure (Table 4). If the number of phases is the same, the label can vary and the terminology may reflect variable activities between frameworks.

The most comprehensive set of elaborated regulatory directives for CCS in a transnational context is the storage collection of the European Union/European Commission (European Commission, 2011a, 2011b, 2011c; European Union, 2009). The 2011 UNFCCC inclusion of CCS as a CDM (UNFCCC, 2011) also includes mandatory and comprehensive RA/RM requirements for capture, transport, storage and post-injection with few notable gaps. Indeed, various UNFCCC representatives and observers believed that this framework will go beyond requirements for CDM and become the new standard for domestic or other international projects as well (IEA, 2012). Given established constitutional powers, Australian and United States' regulatory frameworks for CCS are developed at both national and sub-national state levels. In Australia, State governments are mostly enacting parallel legislation to the Commonwealth lead and jurisdictions have a well-developed regulatory framework in place (IEA, 2014). In the US, the key UIC Class VI Well Program is a federal rule, but States may apply for primacy enforcement responsibility, as completed by the State of North Dakota. The complementary and 
mandatory GHG Reporting Rule, Subpart RR for Geologic Sequestration of Carbon Dioxide is solely administered by the EPA.

In the non-regulatory context, at least one series of best practice manuals has been updated; the NETL reviewed and revised its guidance in light of the National Academies Press Report on the potential for induced seismicity in energy technologies (National Research Council, 2013). A new contribution to elaborated frameworks is being developed by the International Standards Organisation, ISO/TC 265 Carbon dioxide capture, transportation and geological storage, which used the Canadian Standard CSA Z741 as the seed document (CSA Group, 2012). As well, non-government entities are creating on-line (real time) resources where continuous improvement is anticipated through contributions from CCS practitioners (GCCSI, 2019).

\subsection{Risk assessment}

In the regulatory and non-regulatory contexts, RA is almost always suggested for storage site selection and characterisation in order to reduce risk of leakage. However, required assessment activities in the regulatory context vary across jurisdictions. For example, the 2011 UNFCCC Modalities and Procedures for CCS as a CDM (UNFCCC, 2011) includes mandatory and comprehensive RA/RM requirements for capture, transport, storage and post-injection, with few notable gaps. The US EPA UIC Class VI Well Program, approved in 2010, did not include any explicit mandatory requirements for $\mathrm{RA} / \mathrm{RM}$ in the protection of underground sources of drinking water, although associated voluntary guidance is extensive (US Environmental Protection Agency, 2012a, 2012b, 2013a, 2013b, 2013c, 2013d). As noted by Pollak and Wilson (2009), the focus on drinking water constrains the Rule's ability to address other issues for geological storage, such as leakage of $\mathrm{CO}_{2}$ to the surface. However, while 'risk assessment' is not used in the description of requirements for the leakage-focused GHG Reporting Program, Subpart RR - Geologic Sequestration of Carbon Dioxide, permit applications require risk assessment activities (US Environmental Protection Agency, 2017).

There is also evidence of terminological variations for documented activities sourced from different parts of the world. In terms of specified steps, European Commission (EC) sourced directives and guidance (European Commission, 2011a, 2011b, 2011c; European Union, 2009), the UNFCCC (2011) and several non-government contributions (Det Norske Veritas, 2012; NETL, 2017c; World Resources Institute, 2008) list a 4-step RA process - hazard identification, exposure assessment, effects assessment, risk characterisation - but the descriptions of these steps are not consistent in depth or breadth, with the least guidance provided for exposure assessment and risk characterisation. More recently, non-regulatory guidance is modifying RA terminology, notably moving to a 3-step sequence for hazard identification, risk analysis and risk evaluation activities (CSA Group, 2012; Det Norske Veritas, 2013). This may reflect variance between human health $\mathrm{RA} / \mathrm{RM}$ frameworks and those developed from an engineered systems safety assessment perspective (IEAGHG, 2009). While the core structure may be very similar, some assessment components are complementary: human health RA is focused on hazard assessment, effects assessment and consequences, while engineered systems' RA is focused is on "establishing the context and vulnerability of potential receptors and the risk management steps, particularly the treatment of risk, monitoring and review" [IEAGHG, (2009), p.23]. 
Table 2(a) Risk assessment activities included in elaborated frameworks in a regulatory context

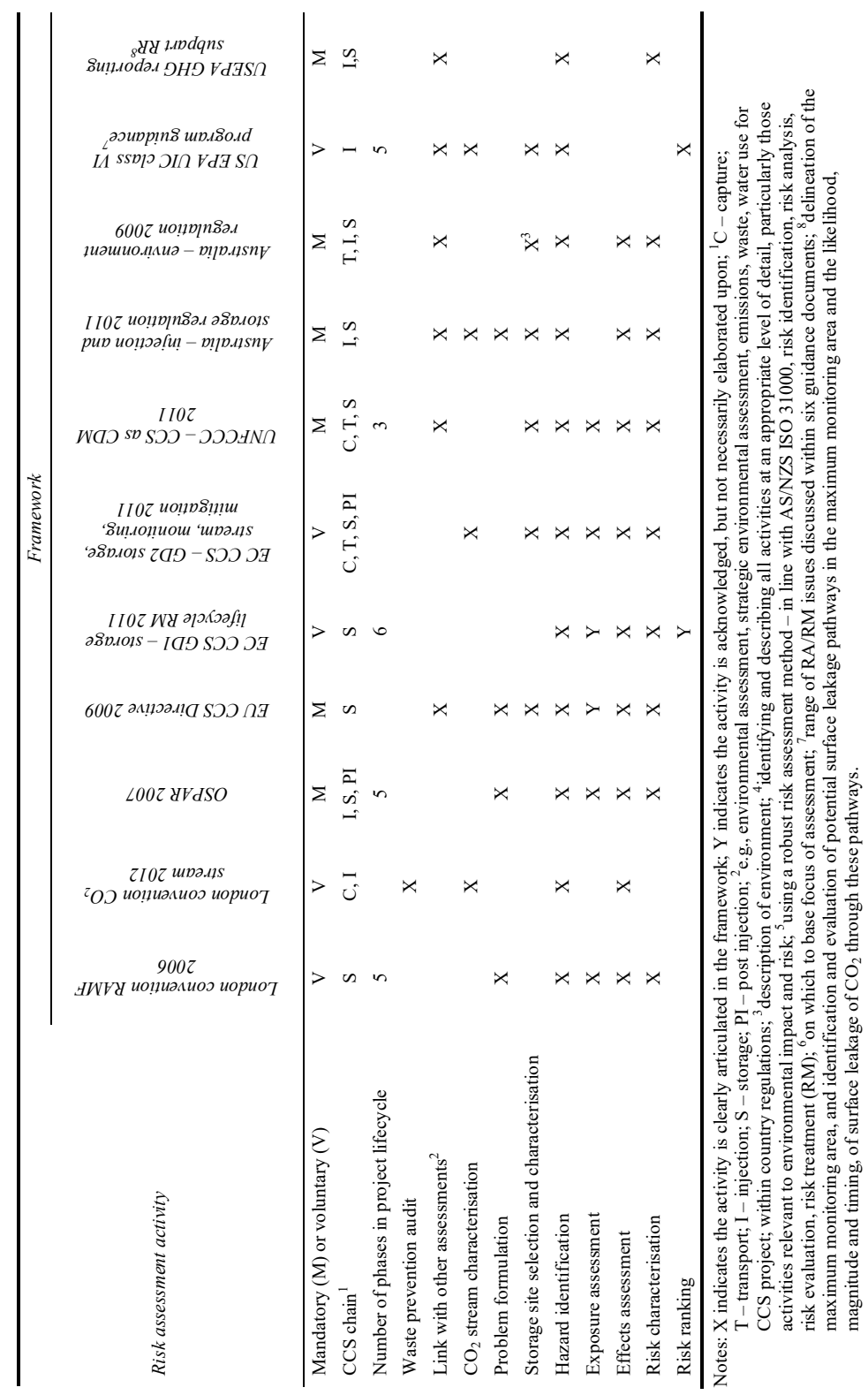


Table 2(b) Risk management activities included in elaborated frameworks in a regulatory context

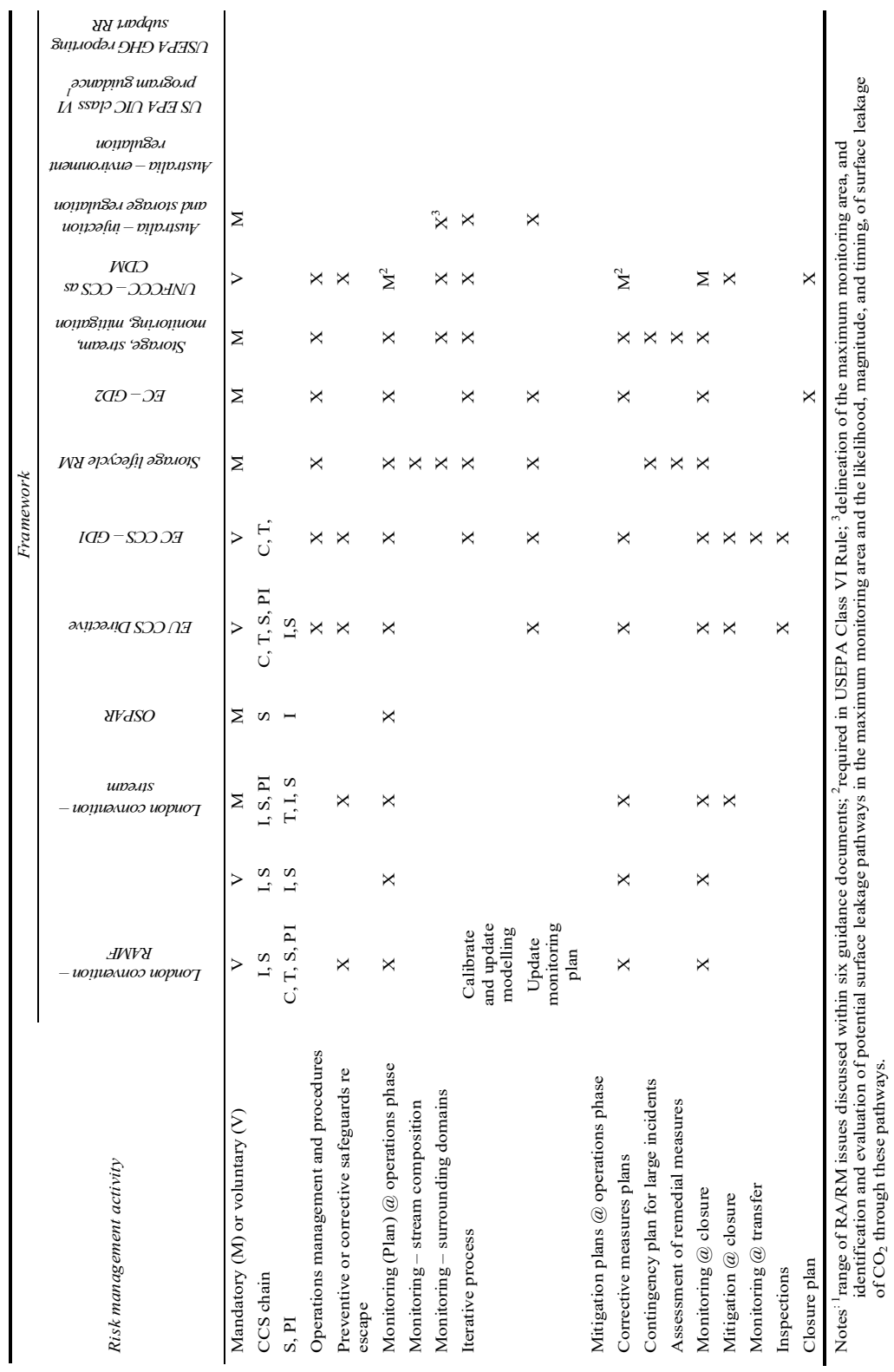


Table 2(c) Other considerations included in elaborated frameworks in a regulatory context

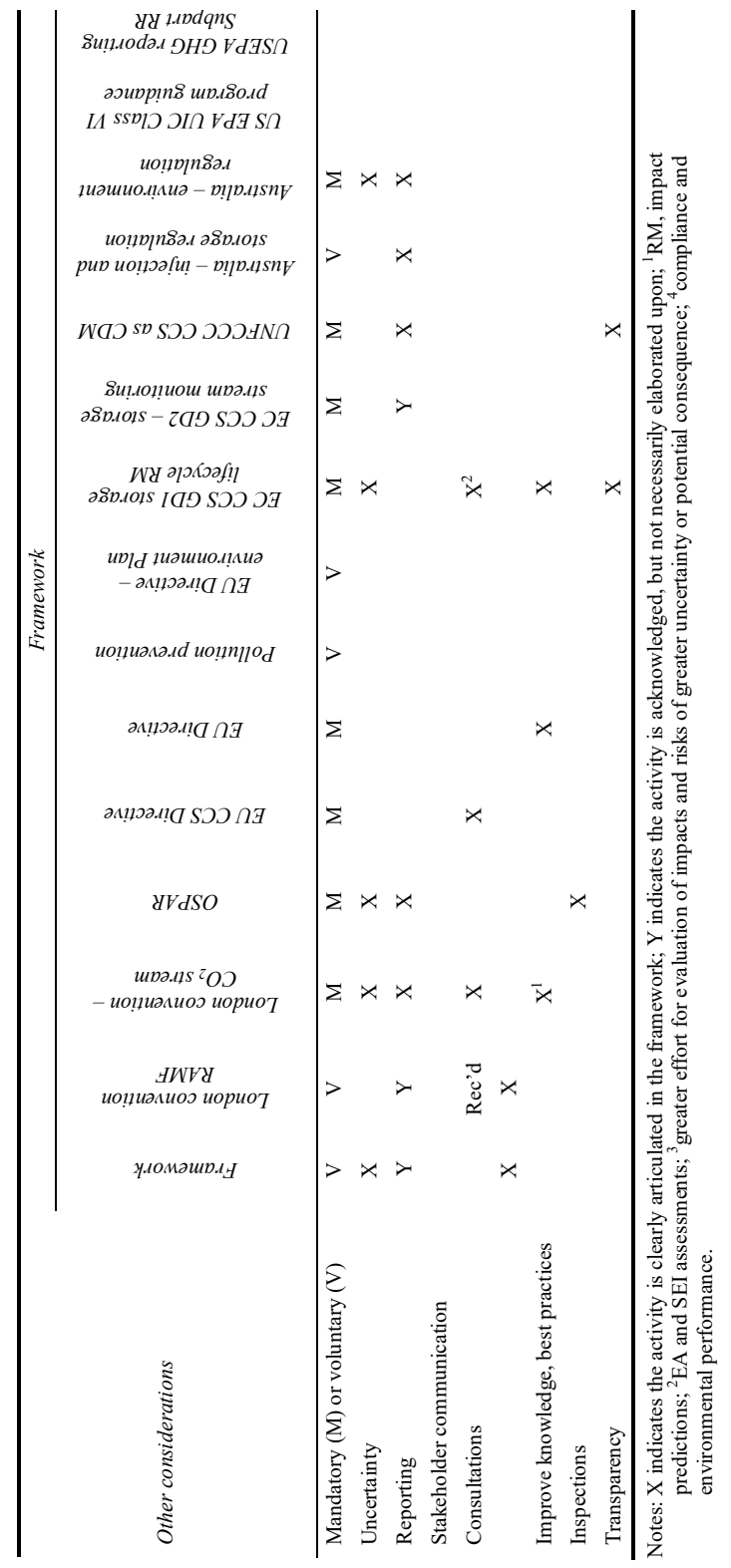


Table 3(a) Risk assessment activities included elaborated frameworks in a non-regulatory context (all are voluntary)

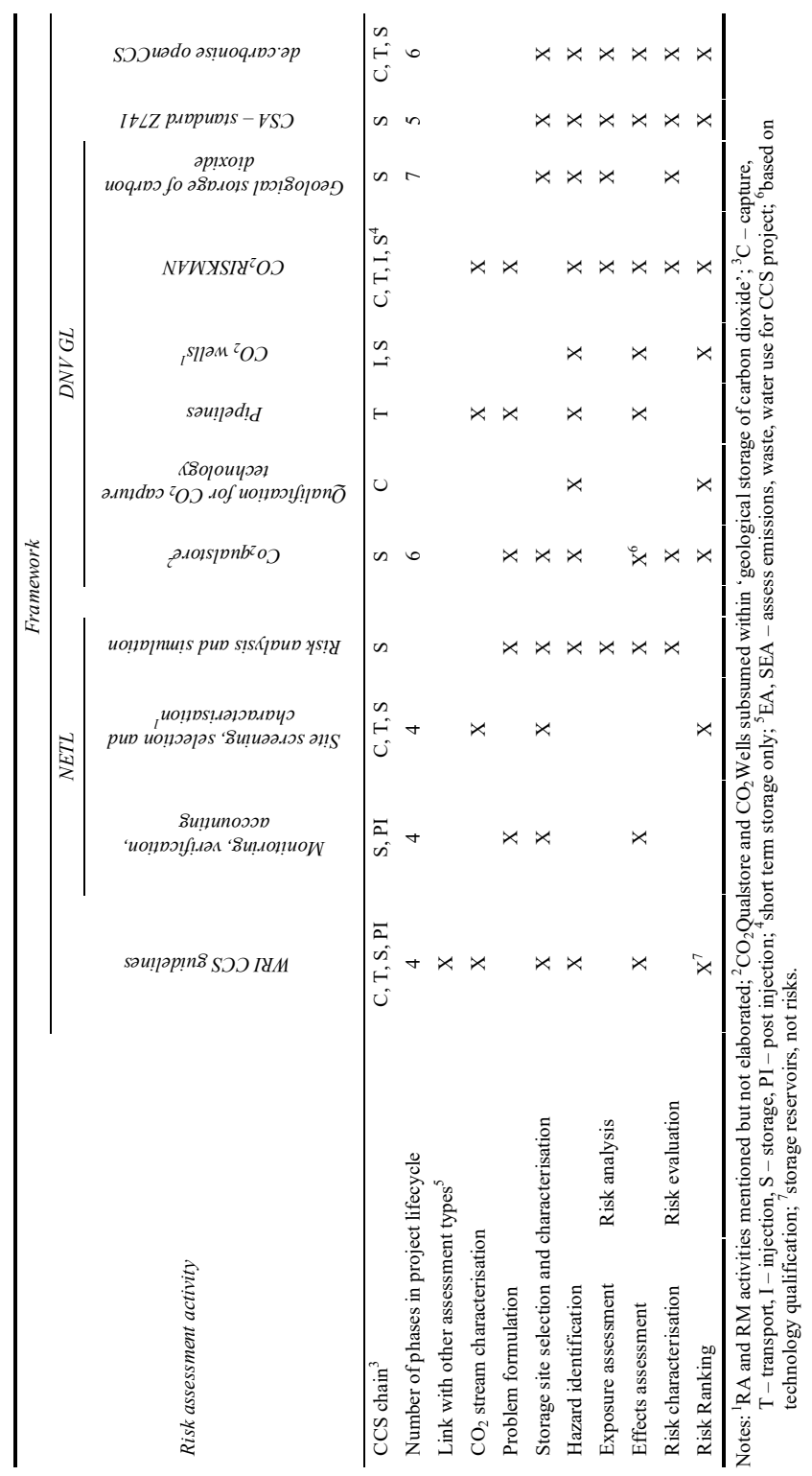


Table 3(b) Risk management activities elaborated frameworks in a non-regulatory context

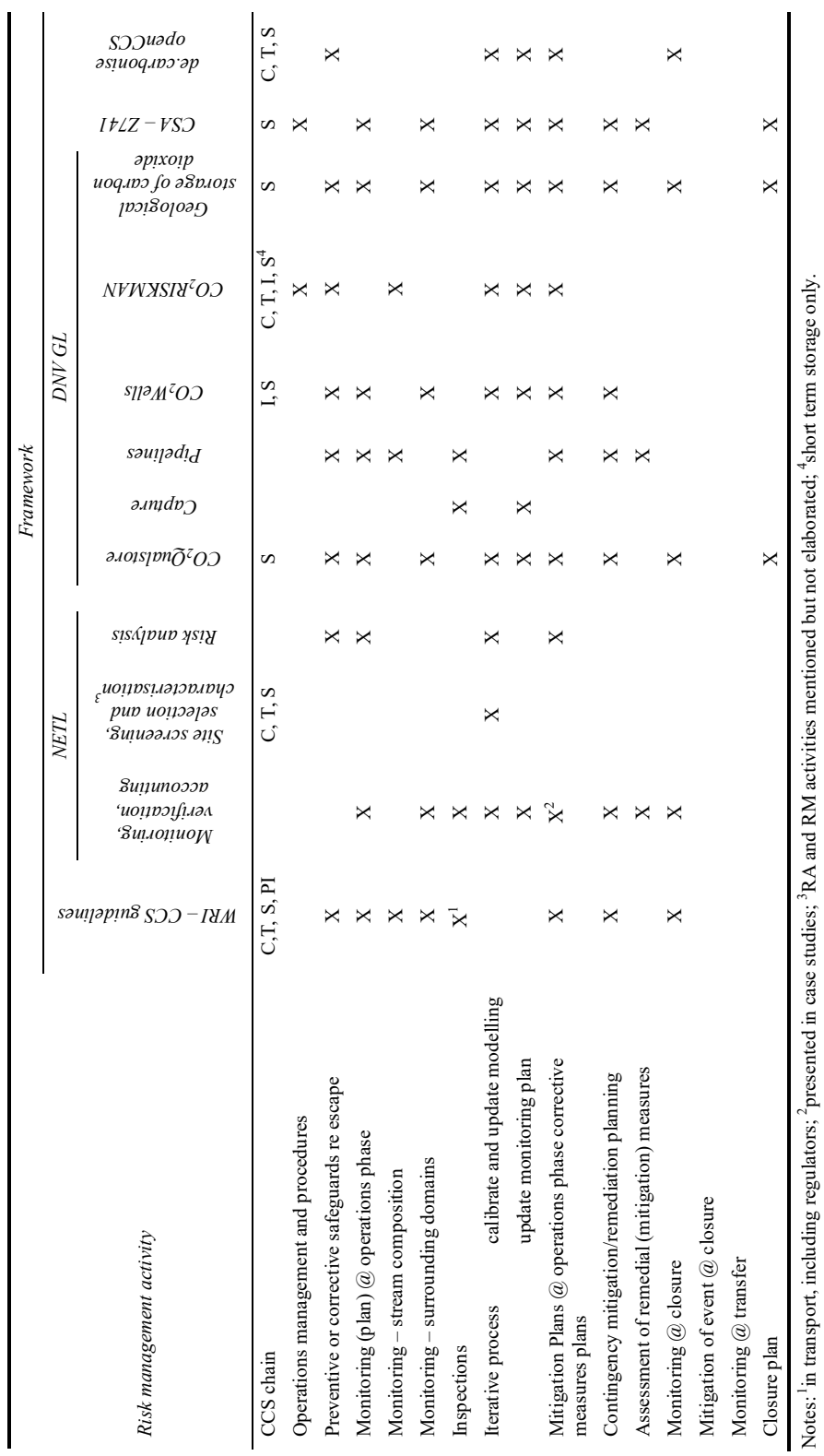


Table 3(c) Other considerations included elaborated frameworks in a non-regulatory context




Table 4 CCS project phases for injection and storage within selected elaborated risk assessment and risk management frameworks




As a separate step, several non-government guidance documents discuss the need for risk ranking, primarily with regard to site selection (CSA Group, 2012; Det Norske Veritas, 2012; World Resources Institute, 2008) and risk management (Det Norske Veritas, 2013). Frameworks may also suggest risk ranking be completed and documented using an expert facilitated workshop/brainstorming session. Several elicitations have been reported: Illinois Basin-Decatur Project, USA (Hnottavange-Telleen et al., 2011); CASSEM Project, Scotland (Polson et al., 2012); and IEAGHG Weyburn-Midale $\mathrm{CO}_{2}$ Monitoring Project, Saskatchewan, Canada (Bowden et al., 2013a, 2013b).

Gaps in the frameworks include a lack of guidance on risk estimation which could provide a quantitative characterisation of the risks associated with CCS. Furthermore, few elaborated regulatory and non-regulatory frameworks link with an assessment of emissions, waste, or water use in CCS; and only a few discuss $\mathrm{CO}_{2}$ stream assessment which could have an effect on injectivity, well integrity and physical aspects of storage (Talman, 2015). DNV's $\mathrm{CO}_{2}$ RISKMAN (2013) addressed the $\mathrm{CO}_{2}$ stream in detail for capture, transport and injection, but not for storage. As also found by Pawar et al. (2015), few documents discuss the RA or consequences of mitigation measures of unintended events.

\subsection{Risk management}

The risk management portion of the elaborated frameworks reviewed here commonly suggest decision making be founded on the risk assessment process. Monitoring is identified as the key RM activity during operations, principally to demonstrate containment in the short term and conformance in the longer term (Jenkins et al., 2015). It is also often required for the closure phase of CCS projects however full elaboration is limited in the regulatory and non-regulatory documents reviewed here.

An iterative process to monitor injection and storage, including the use of results to calibrate and update modelling and then review and possibly revise monitoring activities, is recommended (CSA Group, 2012; Det Norske Veritas, 2012; European Commission, 2011a, 2011b; NETL, 2017a, 2017c, 2017d; UNFCCC, 2011; Wilson et al., 2008). Relatively few documents discuss or require $\mathrm{CO}_{2}$ stream monitoring through the CCS value chain, except for DNV's $\mathrm{CO}_{2}$ RISKMAN as described above. There is also little guidance on monitoring of surrounding (shallow) domains. However, Jenkins et al. (2015) described progress in monitoring and verification as a risk management tool in the ten years since the CCS Special Report (IPCC, 2005), particularly with respect to research and approach for groundwater, soils, vegetation and atmospheric issues.

Monitoring and planning for contingencies is included in RM activities in the non-regulatory context by WRI (Wilson et al., 2008), NETL MMV (2017a), DNV Geological Storage (2012), DNV Pipeline (2010a) and Canadian Standard Z741 (CSA Group, 2012). Contingency planning for large incidents is mandatory in the regulatory context by the UNFCCC-CDM (UNFCCC, 2011) and Australia's Offshore Petroleum and Greenhouse Gas (Environment) Regulation (Australian Government, 2014). $\mathrm{CO}_{2}$ RISKMAN (Det Norske Veritas, 2013) also suggested numerous techniques for major accident hazard risk management using a lifecycle RM approach, with recovery measures for capture, transport, wells and intermediate storage. This guidance does not consider potential longer term impacts to groundwater quality from $\mathrm{CO}_{2}$ or displacement of other reservoir fluids such as brine. Jenkins et al. (2015) suggested that assessment and 
planning for potential significant adverse effects on the environment or other resources are not yet well developed.

As a specific approach, the use of 'as low as reasonably practicable' (ALARP) risk management criteria was identified in the regulatory regime for Australia (environment and safety case) and in the DNV GL's Recommended Practice - Geological Storage of Carbon Dioxide (Det Norske Veritas, 2012) and $\mathrm{CO}_{2}$ RISKMAN Guidance on $\mathrm{CCS} \mathrm{CO}_{2}$ Safety and Environment, Major Accident Hazard Risk Management (Det Norske Veritas, 2013). ALARP is a standard applied to duty-holders that provides some flexibility in risk management where the practicality of risk avoidance is based on consideration of cost, time and complexity. Operators may set goals for their own safety performance rather than following prescriptive requirements.

In Australia, 'reasonably practicable' is an objective test that has been upheld by the High Court (NOPSEMA, 2015). After a risk assessment and assessment of risk control options, in terms of availability and suitability of ways to eliminate the risk, "an operator has to show, through reasoned and supported arguments, that there are no other practical measures that could reasonably be taken to reduce risks further" [NOPSEMA, (2015), p.5]. In Australia, NOPSEMA may also reject a safety case. While the guidance notes that 'good practice' is often enough to identify practicable risk management options, where there is a new technology the use of 'good practice' may not be well established and other evidence would be required (NOPSEMA, 2015).

\subsection{Other risk-based considerations}

Several other important RA/RM issues are addressed variously in the frameworks reviewed here. Common project-based considerations such as uncertainty assessment, stakeholder communication and consultation and the goal of transparency in RA/RM are discussed frequently in non-regulatory documents, but only sparsely in the regulatory context.

With respect to uncertainty, Australia's ALARP guidance for the safety case includes discussion of the use of the precautionary principle in cases with no expert consensus. Moreover, the guidance states that "it is expected that risk related decision making should be made with sufficient certainty and understanding of the both the likelihood and consequence of an event occurring. Where this is not the case a precautionary approach to demonstrate risks are ALARP should be taken" [NOPSEMA, (2015), p.11]. The precautionary principle, as an approach in decision making with respect to environment and human health protection, is not discussed in the context of European-based frameworks such as those published by the IMO (2006), OSPAR Commission (2007) and European Union (2009); neither is the principle discussed within the UNFCCC (2011) modalities and procedures for carbon dioxide capture and storage in geological formations as CDM project activities.

With respect to best practices for public outreach and education, only non-regulatory entities have published guidance documents, for example by the NETL (2017b) and World Resources Institute Guidelines for Community Engagement (Forbes et al., 2010). Stakeholder communication and consultation and the goal of transparency, are addressed by Leiss and Larkin (2019).

As a separate issue for CCS, proponents suggest that carbon capture and utilisation projects (CCUS), such as for enhanced oil recovery operations (EOR), are virtually synonymous with saline sequestration as demonstration sites for climate change 
mitigation. However, EOR projects operate under regulatory regimes where monitoring, measurement and verification are not necessarily required and containment and performance results may not be disclosed publicly (Jenkins et al., 2015). Initiatives are therefore underway to account for EOR in climate change mitigation (IEA, 2015; Wong et al., 2013) and Al Eidan et al. (2015) described the technical challenges in the conversion of EOR to storage projects. While this paper focused on providing a compendium and analysis of RA/RM frameworks applied to sequestration projects, additional research could determine the provisions for environmental and human health $\mathrm{RA} / \mathrm{RM}$ in the regulatory context or in voluntary guidance applied to CCUS.

\section{Conclusions}

This paper provides a compendium of elaborated risk assessment and risk management frameworks that could be applied in the application, review and approval of carbon capture and geological storage projects. Regulatory-based initiatives continue to be deemed of utmost importance to the widespread planning and safe development of CCS projects worldwide and as suggested by the IEA (2010a), projects will be approved through a combination of existing, amended and new laws and regulations that come into effect for specific activities within the CCS value chain. Risk assessment and risk management within the London Convention, the OSPAR Convention, the EU CCS Directive and the UNFCCC CDM are described, as well as provisions enacted by national and state governments in Australia and the United States. Elaborated nonregulatory guidance has also been published, principally by the US NETL, World Resources Institute and DNV GL. Furthermore, several online resources are available to CCS risk management practitioners.

Regulatory-based RA/RM frameworks for CCS focus mainly on injection and storage. Storage site selection and characterisation is often identified as the most effective approach to reduce risk; risk assessment for human health is specified less often than environmental effects; accessible and transparent processes are gaining momentum; and comprehensive risk estimation is not yet promoted. In terms of risk management, the primary mandatory requirement is limited to monitoring, with an iterative approach recommended to monitor and re-assess risk. Other considerations such as uncertainty, stakeholder communication and consultation and the goal of transparency are not elaborated in the regulatory context, while some non-regulatory guidance is focused solely on these activities.

Leading CCS jurisdictions and non-government stakeholders published and updated both print-based and web-based guidance regularly through 2014, however such activities have slowed in the past three years. Overall, the UNFCCC (2011) Modalities and Procedures for CCS as a CDM, directives issued by the European Commission in support of the EU CCS Directive and non-regulatory World Resources Institute (2008), DNV $\mathrm{CO}_{2}$ RISKMAN (2013) and openCCS (GCCSI, 2019) are the most inclusive RA/RM frameworks available. A critical issue is the application of RA/RM to carbon capture utilisation and storage, an activity that is described as similar to geological storage for climate mitigation purposes. 


\section{Acknowledgements}

This research was funded by Carbon Management Canada (CMC), a federally funded Network of Centres of Excellence. The authors also thank three anonymous reviewers.

\section{References}

Al Eidan, A., Bachu, S., Melzer, S., Lars, E.I. and Ackiewicz, M. (2015) Technical Challenges in the Conversion of $\mathrm{CO}_{2}-\mathrm{EOR}$ Projects to $\mathrm{CO}_{2}$ Storage Projects [online] https://www.onepetro.org/conference-paper/SPE-174575-MS (accessed 19 September 2018).

Australian Government (2009) Offshore Petroleum and Greenhouse Gas Storage (Safety) Regulation [online] http://www.comlaw.gov.au/Details/F2010C00422/Download (accessed 22 August 2018).

Australian Government (2011a) Offshore Petroleum and Greenhouse Gas Storage (Greenhouse Gas Injection and Storage) Regulation [online] https://www.comlaw.gov.au/Details/ F2011L01106/Download (accessed 23 July 2018).

Australian Government (2011b) Offshore Petroleum and Greenhouse Gas Storage (Resource Management and Administration) Regulation [online] https://www.legislation.gov.au/Details/ F2016C00692/Download (accessed 7 July 2018).

Australian Government (2011c) Offshore Petroleum and Greenhouse Gas Storage Act, 2006 [online] https://www.comlaw.gov.au/Details/C2011C00044/Download (accessed 23 July 2018).

Australian Government (2014) Offshore Petroleum and Greenhouse Gas Storage (Environment) Regulations, 2009 [online] https://www.comlaw.gov.au/Details/F2014C00210 (accessed 23 August 2018).

Baker and McKenzie (2011) Report to the Global CCS Institute on Legal and Regulatory Developments related to Carbon Capture and Storage between November 2010-June 2011, [online] http://www.globalccsinstitute.com/publications/legal-and-regulatory-developmentsrelated-carbon-capture-and-storage-between-november-2 (accessed 10 October 2018).

Barrett, T. (2015) New Regulations for Offshore Petroleum Wells, no longer available online.

Bowden, A.R., Pershke, D.F. and Chalaturnyk, R. (2013a) 'Biosphere risk assessment for $\mathrm{CO}_{2}$ storage projects', International Journal of Greenhouse Gas Control, Vol. 16, pp.S291-S308, DOI: 10.1016/j.ijggc.2013.02.015.

Bowden, A.R., Pershke, D.F. and Chalaturnyk, R. (2013b) 'Geosphere risk assessment conducted for the IEAGHG Weyburn-Midale $\mathrm{CO}_{2}$ monitoring and storage project', International Journal of Greenhouse Gas Control, Vol. 16, pp.S276-S290, DOI: 10.1016/j.ijggc.2013.02.014.

Carbon Sequestration Leadership Forum (2013) 5th Meeting of the Carbon Sequestration Leadership Forum (CSLF) Ministers, Re-energizing Global Momentum for CCS and Identifying Key Actions Needed for CCS Deployment [online] https://www.cslforum.org/ cslf/sites/default/files/documents/Washington2013/MinisterialCommuniqueWashington1113.pdf (accessed 19 September 2018).

$\mathrm{CO}_{2}$ Capture Project (2010) Update on Selected Regulatory Issues for $\mathrm{CO}_{2}$ Capture and Geological Storage - Final Report [online] http://unfccc.int/resource/docs/2011/smsn/ngo/275.pdf (accessed 10 May 2018).

$\mathrm{CO}_{2}$ Capture Project (2012) Regulatory Challenges and Key Lessons learned from Real World Development of CCS projects - Final Report [online] http://www.co2captureproject.org/ reports/regulatory_study.pdf (accessed 10 May 2018).

Condor, J., Unatrakarn, D., Asghari, K. and Wilson, M. (2011a) 'A comparative analysis of regulations for the geologic storage of carbon dioxide', Energy Procedia, Vol. 4, pp.5895-5902, DOI: 10.1016/j.egypro.2011.02.589. 
Condor, J., Unatrakarn, D., Wilson, M. and Asghari, K. (2011b) 'A comparative analysis of risk assessment methodologies for the geologic storage of carbon dioxide', Energy Procedia, Vol. 4, pp.4036-4043, DOI: 10.1016/j.egypro.2011.02.345.

CSA Group (2012) CSA Z741:2012 Geological Storage of Carbon Dioxide [online] $\mathrm{https}: / /$ store.csagroup.org/ccrz_Products?cartID=\&operation=quickSearch\&searchText=filter codes and standards geological\%20storage\&searchFilter $=$ filter codes and standards\&is $\overline{\mathrm{CSRF}}$ - ${ }_{\mathrm{W}}=$ true \&portalUser $=\&$ store $=\& \mathrm{cclcl}=$ en_US $($ accessed 7 September 2018).

Det Norske Veritas (2010a) Project Specific Guideline for Safe, Reliable and Cost-Effective Transmission of $\mathrm{CO}_{2}$ in Pipelines [online] http://rules.dnvgl.com/docs/pdf/DNV/codes/docs/ 2010-04/RP-J202.pdf (accessed 7 September 2018).

Det Norske Veritas (2010b) Qualification Procedures for $\mathrm{CO}_{2}$ Capture Technology [online] http://rules.dnvgl.com/docs/pdf/DNV/codes/docs/2010-04/RP-J201.pdf (accessed 23 July 2018).

Det Norske Veritas (2012) Geological Storage of Carbon Dioxide [online] https://www.dnvgl.com/services/carbon-capture-utilisation-and-storage-ccus--5196 (accessed 23 July 2018).

Det Norske Veritas (2013) $\mathrm{CO}_{2} \mathrm{RISKMAN}$, Guidance on $\mathrm{CCS} \mathrm{CO}_{2}$ Safety and Environment, Major Accident Hazard Risk Management, Level 1, 2, 3 and 4 [online] https://www.dnvgl.com/ oilgas/joint-industry-projects/ongoing-jips/co2riskman.html (accessed 6 September 2018).

Dixon, T., McCoy, S.T. and Havercroft, I. (2015) 'Legal and regulatory developments on CCS', International Journal of Greenhouse Gas Control, Vol. 40, pp.431-448, DOI: 10.1016/j.ijggc.2015.05.024.

European Commission (2011a) CCS Directive on the Geological Storage of Carbon Dioxide: Guidance Document 1, $\mathrm{CO}_{2}$ Storage Life Cycle Risk Management Framework [online] https://ec.europa.eu/clima/policies/lowcarbon/ccs/implementation_en\#tab-0-1 (accessed 4 August 2018).

European Commission (2011b) CCS Directive on the Geological Storage of Carbon Dioxide: Guidance Document 2, Characterisation of the Storage Complex, $\mathrm{CO}_{2}$ Stream Composition, Monitoring and Corrective Measures [online] https://ec.europa.eu/clima/policies/lowcarbon/ ccs/implementation_en\#tab-0-1 (accessed 4 August 2018).

European Commission (2011c) CCS Directive on the Geological Storage of Carbon Dioxide: Guidance Document 3, Criteria for Transfer of Responsibility to the Competent Authority [online] https://ec.europa.eu/clima/policies/lowcarbon/ccs/implementation_en\#tab0-1 (accessed 4 August 2018).

European Commission (2012a) Commission Opinion of 28.2.2012 Relating to the Draft Permit for the Permanent Storage of Carbon Dioxide in Block Section P18-4 of Block Section P18a of the Dutch Continental Shelf, in accordance with Article 10(1) of Directive 2009/31/EC of 23 April 2009 on the Geological Storage of Carbon Dioxide [online] https://ec.europa.eu/clima/sites/clima/files/lowcarbon/ccs/implementation/docs/c_2012_1236_ en.pdf (accessed 18 September 2018).

European Commission (2012b) Commission Regulation (EU) No 601/2012 on the Monitoring and Reporting of Greenhouse Gas Emissions pursuant to Directive 2003/87/EC of the European Parliament and of the Council [online] http://eur-lex.europa.eu/legal-content/EN/TXT/PDF/ ?uri=CELEX:32012R0601\& from=EN (accessed 9 May 2018).

European Commission. (2018) Reports on the implementation of the CCS Directive [online] https://ec.europa.eu/clima/policies/lowcarbon/ccs/implementation en (accessed 20 August 2018).

European Union (1985) Environmental Assessment - Brussels, BE. European Union, Council Directive 85/337/EEC [online] http://eur-lex.europa.eu/LexUriServ/LexUriServ.do?uri= CONSLEG:1985L0337:20090625:EN:PDF (accessed 4 August 2018).

European Union (2008) Directive 2008/1/EC concerning Integrated Pollution Prevention and Control [online] http://eur-lex.europa.eu/LexUriServ/LexUriServ.do?uri=OJ:L:2008: 024:0008:0029:en:PDF (accessed 18 May 2018). 
European Union (2009) Directive 2009/31/EC on the Geological Storage of Carbon Dioxide and amending other Directives [online] http://eur-lex.europa.eu/LexUriServ/LexUriServ.do?uri= OJ:L:2009:140:0114:0135:EN:PDF (accessed 4 August 2018).

European Union (2014) Directive 2014/52/EU of the European Parliament and of the Council, amending Directive 2011/92/EU on the Assessment of the Effects of Certain Public and Private Projects on the Environment [online] http://eur-lex.europa.eu/legal-content/EN/ TXT/PDF/?uri=CELEX:32014L0052\&from=EN (accessed 18 May 2018).

Forbes, S.M., Almendra, F. and Ziegler, M.S. (2010) CCS and Community Engagement [online] http://pdf.wri.org/ccs_and_community_engagement.pdf (accessed 4 August 2018).

Forbes, S.M., Verma, P., Friedmann, S.J., Curry, T.E., Wade, S.M. and Venezia, J. (2009) 'WRI CCS guidelines and emerging geologic sequestration regulations: a comparative assessment', Energy Procedia, Vol. 1, No. 1, pp.1759-1766, DOI: 10.1016/j.egypro.2009.01.230.

Gammer, D., Green, A., Holloway, S. and Smith, G. (2011) The Energy Technologies Institute's

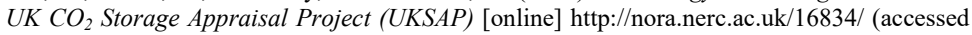
4 August 2018).

GCCSI (2010) The Global Status of CCS 2010 [online] http://www.globalccsinstitute.com/ publications/global-status-ccs-2010 (accessed 10 May 2018).

GCCSI (2013) Bridging the Gap: An Analysis and Comparison of Legal and Regulatory Frameworks for $\mathrm{CO}_{2}$-EOR and $\mathrm{CO}_{2}$-CCS [online] http://decarboni.se/sites/default/files/ publications/1 18951/bridging-gap-analysis-comparison-legal-regulatory-frameworks-eorccs.pdf (accessed 10 May 2018).

GCCSI (2014) The global status of CCS [online] http://decarboni.se/sites/default/files/publications/ 180923/global-status-ccs-2014.pdf (accessed 16 August 2018).

GCCSI (2015) Global CCS Institute CCS Legal and Regulatory Indicator: A Global Assessment of National Legal and Regulatory Regimes for Carbon Capture and Storage [online] http://hub.globalccsinstitute.com/sites/default/files/publications/196443/global-ccs-instituteccs-legal-regulatory-indicator.pdf (accessed 7 September 2018).

GCCSI (2017) The Global Status of CCS [online] https://www.globalccsinstitute.com/projects/ large-scale-ccs-projects (accessed 30 August 2018).

GCCSI (2019) openCCS Project Handbook [online] https://www.globalccsinstitute.com/resources/ publications-reports-research/?search=openCCS+Project+Handbook (accessed 23 July 2018).

Government of South Australia (2012) Fitness for Purpose Assessment Guideline, June, prepared under the Petroleum and Geothermal Energy Act 2000 (SA) [online] http://www.petroleum. statedevelopment.sa.gov.au/_data/assets/pdf_file/0007/259225/FFP_Review_Guideline_June 2012.pdf (accessed 18 May 2018).

Government of South Australia (2018) Petroleum and Geothermal Energy Act and Regulations [online] http://petroleum.statedevelopment.sa.gov.au/legislation_and_compliance/petroleum _ and_geothermal_energy_act_and_Regulations (accessed 18 May 2018).

Hnottavange-Telleen, K., Chabora, E., Finley, R.J., Greenberg, S.E. and Marsteller, S. (2011) 'Risk management in a large-scale $\mathrm{CO}_{2}$ geosequestration pilot project, Illinois, USA', Energy Procedia, Vol. 4, pp.4044-4051, DOI: 10.1016/j.egypro.2011.02.346.

IEA (2009) Technology Roadmap: Carbon Capture and Storage [online] https://www.iea.org/ publications/freepublications/publication/CCSRoadmap2009.pdf (accessed 10 October 2018).

IEA (2010a) Carbon Capture and Storage Model Regulatory Framework [online] http://www.iea.org/publications/freepublications/publication/model_framework.pdf (accessed 7 September 2018).

IEA (2010b) Carbon Capture and Storage: Legal and Regulatory Review [online] http://www.iea.org/publications/freepublications/publication/carbon-capture-and-storagelegal-and-regulatory-review---edition-1.html (accessed 7 September 2018).

IEA (2011) Carbon Capture and Storage Legal and Regulatory Review [online] http://www.iea.org/publications/freepublications/publication/ccs_legal.pdf (accessed 10 May 2018). 
IEA (2012) CCS Outcomes from Durban and Next Steps for CCS in the CDM [online] https://www.iea.org/workshops/web-conference----020212.html (accessed 18 May 2018).

IEA (2013) Technology Roadmap Carbon Capture and Storage [online] https://www.iea.org/ publications/freepublications/publication/TechnologyRoadmapCarbonCaptureandStorage.pdf (accessed 16 August 2018).

IEA (2014) Carbon Capture and Storage: Legal and Regulatory Review [online] https://www.iea.org/publications/insights/insightpublications/CCSReview_4thEd_FINAL.pdf (accessed 10 May 2018).

IEA (2015) Storing $\mathrm{CO}_{2}$ through Enhanced Oil Recovery [online] https://www.iea.org/ publications/insights/insightpublications/storing-co2-through-enhanced-oil-recovery.html (accessed 8 September 2018).

IEA (2016) 20 Years of Carbon Capture and Storage [online] https://www.iea.org/ publications/freepublications/publication/20YearsofCarbonCaptureandStorage_WEB.pdf (accessed 20 August 2018).

IEA (2018) CCS Law and Regulations Database [online] https://www.iea.org/ccsdatabase/ (accessed 8 September 2018).

IEAGHG (2009) 'Review of international state of the art in risk assessment guidelines and proposed terminology for use in $\mathrm{CO}_{2}$ geological storage', IEA Greenhouse Gas $R \& D$ Programme, IEA Environmental Projects Ltd., Cheltenham, UK [online] http://www.globalccsinstitute.com/publications/review-international-state-art-risk-assessmentguidelines-and-proposed-terminology-use (accessed 4 August 2018).

International Maritime Organization (IMO) (2006) 'London Convention - Risk Assessment and Management Framework for $\mathrm{CO}_{2}$ Sequestration in Sub-Seabed Geological Structures (RAMF) [online] http://www.imo.org/blast/mainframemenu.asp?topic_id=1615 (accessed 4 August 2018).

International Maritime Organization (IMO) (2012) London Protocol: Specific Guidelines for Assessment of Carbon Dioxide Streams for Disposal into Sub-Seabed Geological Formations [online] http://www.imo.org/blast/blastDataHelper.asp?data_id=31124\&filename=2012SPECI FICGUIDELINESFORTHEASSESSMENTOFCARBONDIOXIDE.pdf (accessed 4 August 2018).

IPCC (2005) IPCC Special Report on Carbon Dioxide Capture and Storage [online] http://www.ipcc.ch/pdf/special-reports/srccs/srccs_wholereport.pdf (accessed 16 August 2018).

IPCC (2014) Summary for Policy Makers, Mitigation of Climate Change [online] http://www.ipcc.ch/report/ar5/wg3/ (accessed 16 August 2018).

ISO (2018) Standards Catalogue - ISO/TC 265, Carbon Dioxide Capture, Transportation, and Geological Storage [online] https:/www.iso.org/committee/648607/x/catalogue/p/0/u/1/ $\mathrm{w} / 0 / \mathrm{d} / 0$ (accessed 20 August 2018).

Jenkins, C., Chadwick, A. and Hovorka, S.D. (2015) 'The state of the art in monitoring and verification - ten years on', International Journal of Greenhouse Gas Control, Vol. 40, pp.312-349, DOI: 10.1016/j.ijggc.2015.05.009.

Kansas State Corporation Commission (2010) Permanent Administrative Regulations Article 3 Production and Conservation of Oil and Gas [online] http://www.kssos.org/pubs/register\% 5C2010\%5CVol_29_No_06_February_11_2010_p_165-196.pdf (accessed 23 August 2018).

Keith, D.W., Giardina, J.A., Morgan, M.G. and Wilson, E.J. (2005) 'Regulating the underground injection of $\mathrm{CO}_{2}$ ', Environmental Science and Technology, Vol. 39, pp.499A-505A.

Klass, A.B. and Wilson, E. (2008) 'Climate change and carbon sequestration: assessing a liability regime for long-term storage of carbon dioxide', Emory Law Journal, Vol. 58, No. 1, pp.103-80.

Larkin, P., Leiss, W., Arvai, J., Gracie, R.G., Fall, M., Dusseault, M.D., Heyes, A. and Krewski, D. (2019) 'An integrated risk management framework for carbon capture and storage: a Canadian perspective', International Journal of Risk Assessment and Management, in this issue. 
Leiss, W. and Krewski, D. (2019) 'Environmental scan and issue awareness: risk management challenges for CCS', International Journal of Risk Assessment and Management, in this issue.

Leiss, W. and Larkin, P. (2019) 'Risk communication and public engagement in CCS projects: the foundations of public acceptability', International Journal of Risk Assessment and Management, in this issue.

National Energy Technology Laboratory (NETL) (2013) Carbon Storage Systems and Well Management Activities [online] https://www.netl.doe.gov/research/coal/carbonstorage/strategic-program-support/best-practices (accessed 4 August 2018).

National Energy Technology Laboratory (NETL) (2017a) Best Practices: Monitoring, Verification, and Accounting (MVA) of Geologic Storage Projects [online] https://www.netl.doe.gov/ File\%20Library/Research/Carbon-Storage/Project-Portfolio/BPM-MVA-2012.pdf (accessed 7 September 2018).

National Energy Technology Laboratory (NETL) (2017b) Best Practices: Public Outreach and Education for Geologic Storage Projects [online] https://www.netl.doe.gov/File\%20Library/ Research/Carbon-Storage/Project-Portfolio/BPM_PublicOutreach.pdf (accessed 7 September 2018).

National Energy Technology Laboratory (NETL) (2017c) Best Practices: Risk Management and Simulation for Geologic Storage Projects [online] https://www.netl.doe.gov/File\%20Library/ Research/Carbon-Storage/Project-Portfolio/BPM_RiskAnalysisSimulation.pdf (accessed 7 September 2018).

National Energy Technology Laboratory (NETL) (2017d) Best Practices: Site Screening, Site Selection, and Site Characterization for Geologic Storage Projects [online] https://www.netl.doe.gov/File\%20Library/Research/Carbon-Storage/Project-Portfolio/BPMSiteScreening.pdf (accessed 7 September 2018).

National Research Council (2013) Induced Seismicity Potential in Energy Technologies [online] https://www.nap.edu/catalog/13355/induced-seismicity-potential-in-energy-technologies (accessed 7 September 2018).

NOPSEMA (2015) Guidance Note: ALARP [online] https://www.nopsema.gov.au/assets/Guidancenotes/A138249.pdf (accessed 19 June 2018).

NOPSEMA (2016) Well Operations Management Plan Content and Level of Detail, N-04600GN1602, Revision 1, June 2016 [online] https://www.nopsema.gov.au/assets/Guidancenotes/A461074.pdf (accessed 7 July 2018).

NOPSEMA (2018a) Environment Resources [online] https://www.nopsema.gov.au/environmentalmanagement/environment-resources/ (accessed 7 September 2018).

NOPSEMA (2018b) Well Integrity Resources [online] https://www.nopsema.gov.au/wellintegrity/well-integrity-resources/ (accessed 10 October 2018).

OSPAR Commission (2007) OSPAR Guidelines for Risk Assessment and Management of Storage of $\mathrm{CO}_{2}$ Streams in Geological Formations [online] http://www.ieaghg.org/docs/risk/Mtg03/ GL\%20and\%20FRAM_ANNEX07.pdf (accessed 4 August 2018).

Pawar, R.J., Bromhal, G.S., Carey, J.W., Foxall, W., Korre, A., Ringrose, P.S., Tucker, O., Watson, M.N. and White, J.A. (2015) 'Recent advances in risk assessment and risk management of geologic $\mathrm{CO}_{2}$ storage', International Journal of Greenhouse Gas Control, Vol. 40, pp.292-311, DOI: 10.1016/j.ijggc.2015.06.014.

Pollak, M. and Wilson, E.J. (2009) 'Regulating geologic sequestration in the United States: early rules take divergent approaches', Environmental Science and Technology, Vol. 43, No. 9, pp.3035-3041.

Polson, D., Curtis, A. and Vivalda, C. (2012) 'The evolving perception of risk during reservoir evaluation projects for geological storage of $\mathrm{CO}_{2}$ ', International Journal of Greenhouse Gas Control, Vol. 9, pp.10-23, DOI: 10.1016/j.ijggc.2012.02.010.

Queensland Government (2009) Greenhouse Gas Storage Act [online] https://www.legislation.qld.gov.au/view/html/inforce/current/act-2009-003 (accessed 18 May 2018). 
Queensland Government (2010) Greenhouse Gas Storage Regulation 2010 [online] https://www.legislation.qld.gov.au/LEGISLTN/SLS/2010/10SL058.pdf (accessed 18 May 2018).

Quintessa Ltd. (2018) $\mathrm{CO}_{2}$ FEP Database [online] https://www.quintessa.org/co2fepdb/v2.0.0/ PHP/frames.php (accessed 16 August 2018).

State of Mississippi (2013) Title 53 - Oil, Gas, and Other Minerals. Chapter 11, Mississippi Geologic Sequestration of Carbon Dioxide Act [online] http://law.justia.com/codes/ mississippi/2013/title-53/chapter-11 (accessed 18 May 2018).

State of North Dakota (2009) CHAPTER 38-22, Carbon Dioxide Underground Storage [online] http://www.legis.nd.gov/cencode/t38c22.pdf (accessed 18 May 2018).

State of Victoria (2008) Greenhouse Gas Geological Sequestration Act. No. 61 of 2008 [online] http://www.legislation.vic.gov.au/Domino/Web_Notes/LDMS/PubStatbook.nsf/f932b66241ec flb7ca256e92000e23be/7E4801FE0E8E3A55CA-2574F80019A141/\$FILE/08-61a.pdf (accessed 18 May 2018).

State of Victoria (2009) Greenhouse Gas Geological Sequestration Regulations [online] http://www.austlii.edu.au/au/legis/vic/consol_reg/gggsr2009507/(accessed 18 May 2018).

Stenhouse, M.J., Gale, J. and Zhou, W. (2009) 'Current status of risk assessment and regulatory frameworks for geological $\mathrm{CO}_{2}$ storage', Energy Procedia, Vol. 1, No. 1, pp.2455-2462, DOI: 10.1016/j.egypro.2009.02.007.

Talman, S. (2015) 'Subsurface geochemical fate and effects of impurities contained in a $\mathrm{CO}_{2}$ stream injected into a deep saline aquifer: what is known', International Journal of Greenhouse Gas Control, Vol. 40, pp.267-291, DOI: 10.1016/j.ijggc.2015.04.019.

The Crown Estate and British Geological Survey (2016) $\mathrm{CO}_{2}$ Stored [online] http://www.co2stored.co.uk/home/index (accessed 4 August 2018).

Triple, Ricardo-AEA and TNO (2015) Support to the review of Directive 2009/31/EC on the geological storage of carbon dioxide (CCS Directive) [online] http://publications.europa.eu/ resource/cellar/3f0867e1-8e88-11e5-b8b7-01aa75ed71a1.0001.01/DOC_1 (accessed 28 September 2018).

United Nations Framework Convention on Climate Change (UNFCCC) (2011) Modalities and Procedures for Carbon Dioxide Capture and Storage in Geological Formations as Clean Development Mechanism Project Activities [online] http://unfccc.int/resource/docs/ 2011/cmp7/eng/10a02.pdf\#page=13 (accessed 23 August 2018).

US Environmental Protection Agency (2010) Report of the Interagency Task Force on Carbon Capture and Storage [online] https://www.energy.gov/sites/prod/files/2013/04/f0/ CCSTaskForceReport2010_0.pdf (accessed 4 August 2018).

US Environmental Protection Agency (2011) Underground Injection Control (UIC) Program: Federal Requirements for Class VI Injection Wells for the Geologic Sequestration of Carbon Dioxide [online] http://www.regulations.gov/document?D=EPA-HQ-OW-2008-0390-0395 (accessed 4 August 2018).

US Environmental Protection Agency (2012a) Geologic Sequestration of Carbon Dioxide Underground Injection Control (UIC) Program Class VI Well Construction Guidance [online] https://www.epa.gov/uic/final-class-vi-guidance-documents (accessed 4 August 2018).

US Environmental Protection Agency (2012b) Geologic Sequestration of Carbon Dioxide Underground Injection Control (UIC) Program Class VI Well Project Plan Development Guidance [online] https://www.epa.gov/uic/final-class-vi-guidance-documents (accessed 4 August 2018).

US Environmental Protection Agency (2013a) Geologic Sequestration of Carbon Dioxide Underground Injection Control (UIC) Program Class VI Well Area Review Evaluation and Corrective Action [online] https://www.epa.gov/uic/final-class-vi-guidance-documents (accessed 4 August 2018). 
US Environmental Protection Agency (2013b) Geologic Sequestration of Carbon Dioxide Underground Injection Control (UIC) Program Class VI Well Draft Guidance - Program on Transitioning Class II to Class VI Wells [online] https://www.epa.gov/uic/draft-class-viguidance-documents-closed-public-comment (accessed 20 August 2018).

US Environmental Protection Agency (2013c) Geologic Sequestration of Carbon Dioxide Underground Injection Control (UIC) Program Class VI Well Site Characterization Guidance [online] https://www.epa.gov/uic/final-class-vi-guidance-documents (accessed 4 August 2016).

US Environmental Protection Agency (2013d) Geologic Sequestration of Carbon Dioxide Underground Injection Control (UIC) Program Class VI Well Testing and Monitoring Guidance [online] https://www.epa.gov/uic/final-class-vi-guidance-documents (accessed 4 August 2018).

US Environmental Protection Agency (2017) Greenhouse Gas Reporting Program [online] https://www.epa.gov/ghgreporting/rulemaking-notices-ghg-reporting (accessed 7 September 2018).

US Environmental Protection Agency (2018a) EPA Approves First Underground Injection Control Program Primacy for Carbon Sequestration Wells to North Dakota [online] https://www.epa.gov/newsreleases/epa-approves-first-underground-injection-control-programprimacy-carbon-sequestration (accessed 20 August 2018).

US Environmental Protection Agency (2018b) Part 98 - Mandatory Greenhouse Gas Reporting [online] https://www.ecfr.gov/cgi-bin/text-idx?c=ecfr\&SID=be77ce6e756f0befaa0dd9574 $3 \mathrm{e} 3342 \mathrm{e} \&$ tpl=/ecfrbrowse/Title40/40cfr98_main_02.tpl (accessed 20 August 2018).

Western Australia (2003) Barrow Island Act 2003 [online] https://www.legislation.wa.gov.au/ legislation/statutes.nsf/main_mrtitle_76_homepage.html (accessed 18 May 2018)

Western Australia (2013) Petroleum and Geothermal Energy Legislation Amendment Bill 2013 [online] http://www.parliament.wa.gov.au/Parliament/Bills.nsf/8B5378BC4E4367FA48257B 8800214A76/\$File/Bill013-1.pdf (accessed 18 May 2018).

Wilson, E.J., Johnson, T.L. and Keith, D.W. (2003) 'Regulating the ultimate sink: managing the risks of geologic $\mathrm{CO}_{2}$ storage', Environmental Science and Technology, Vol. 37, No. 16, pp.3476-3483, DOI: $10.1021 / \mathrm{es} 021038$.

Wilson, E.J., Morgan, M.G., Apt, J., Bonner, M., Bunting, C., Gode, J., Haszeldine, R.S., Jaeger, C.C., Keith, D.W., McCoy, S.T., Pollak, M.F., Reiner, D.M., Rubin, E.S., Torvanger, A., Ulardic, C., Vajjhala, S.P., Victor, D.G. and Wright, I.W. (2008) 'Regulating the geological sequestration of $\mathrm{CO}_{2}$ ', Environmental Science and Technology, Vol. 42, No. 8, pp.2718-2722.

Wong, R., Goehner, A. and McCulloch, M. (2013) Net Greenhouse Gas Impact of Storing $\mathrm{CO}_{2}$ through Enhanced Oil Recovery (EOR), An Analysis of On-site and Downstream GHG Emissions from $\mathrm{CO}_{2}$-EOR Crude Oil Production in Western Canada [online] http://www.pembina.org/reports/ico2n-eor-full-report.pdf (accessed 20 September 2018).

World Resources Institute (2008) CCS Guidelines for Carbon Dioxide Capture, Transport, and Storage, Forbes, S.M., Verma, P., Curry, T.E., Friedmann, S.J. and Wade, S.M. (Eds.) WRI, Washington [online] http://pdf.wri.org/ccs_guidelines.pdf (accessed 4 August 2018).

World Resources Institute (2012) WRI Launches New CCS Regulatory Matrix [online] http://www.wri.org/blog/2012/04/wri-launches-new-ccs-regulatory-matrix (accessed 7 September 2018). 